\title{
The meaning of retrograde coronary flow after primary $\mathrm{PCl}$
}

\author{
Ivana Rakocevic ${ }^{1}$, Vojislav Giga ${ }^{1,2}$, Marija Petrovic ${ }^{1}$, Nikola Boskovic ${ }^{2}$, Milan Dobrić ${ }^{1,2}$, \\ Branko Beleslin ${ }^{1,2}$, Ana Djordjevic Dikic ${ }^{1,2}$ \\ ${ }^{1}$ Cardiology Clinic, Clinical centre of Serbia, Belgrade, ${ }^{2}$ Faculty of medicine, University of Belgrade, Belgrade
}

Abstract Coronary collateral arteries are alternative conduits for blood flow in obstructive coronary heart disease (CAD). Collateral circulation is important in preserving ventricular function in coronary artery disease with total occlusion. Still, during exercise these collaterals are often limited in their functional reserve. This case demonstrates unusual presentation of stress echocardiography (SEcho) and coronary flow reserve (CFR) in the patient after primary percutaneous coronary intervention $(\mathrm{pPCl})$. Due to the limited area of myocardial ischemia provoked with exercise and retrograde coronary flow with the value of CFR correspondent to excellent collaterals, the patient was left on medical therapy, even thou the repeated coronary angiography showed complete in-stent occlusion of the proximal to middle LAD with well-developed collaterals.

Key Words coronary collaterals, coronary flow reserve

\section{Introduction}

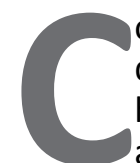
oronary collateral arteries are alternative conduits for blood flow in obstructive coronary heart disease $(C A D)^{1}$. Coronary flow in collaterals may be visualized by angiography to certain extent, but may be also functionally evaluated non-invasively by transthoracic Doppler echocardiography by the means of coronary flow and coronary flow reserve, which is in the presence of occluded artery retrograde ${ }^{2}$. This case demonstrates unusual presentation of stress echocardiography (secho) and coronary flow reserve (CFR) in the patient after primary percutaneous coronary intervention ( $\mathrm{PPCl}$ ).

\section{Case report}

We report the case of 30 years old female patient who was referred to our department for exercise secho test.

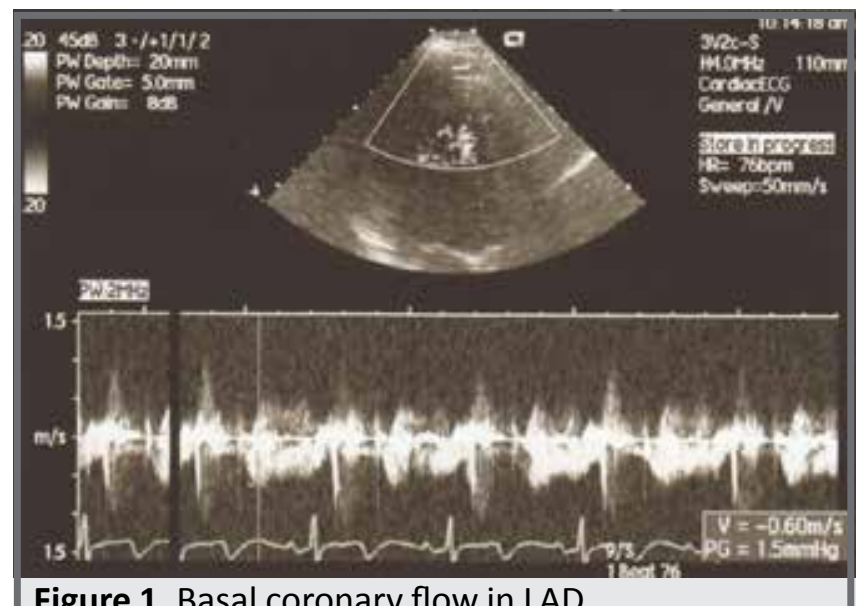

When she was 22 years old, she suffered non-STEMI anterior wall myocardial infarction, treated with one DES implantation in proximal LAD. Right and circumflex coronary artery were without significant stenosis. She had long smoking history and a family history of $\mathrm{CHD}$ (including her father and grandfather).

In the last few months, she starts complaining of angina, but only provoked on cold weather. A physical examination showed normal blood pressure (BP) of $100 / 60 \mathrm{mmHg}$, pulse of 65 beats/minute (bpm). Heart rhythm was regular and without murmurs. There were no pathologic findings on lung auscultation. Echocardiography showed normal left ventricle with preserved ejection fraction of $60 \%$ with no significant wall motion abnormalities. For eight years she was taking aspirin, bisoprolol and atorvastatin.

She underwent treadmill exercise test (Bruce protocol). During the peak phase of stress testing (max pulse 158 bpm) she didn't exhibit any symptoms. ECG showed

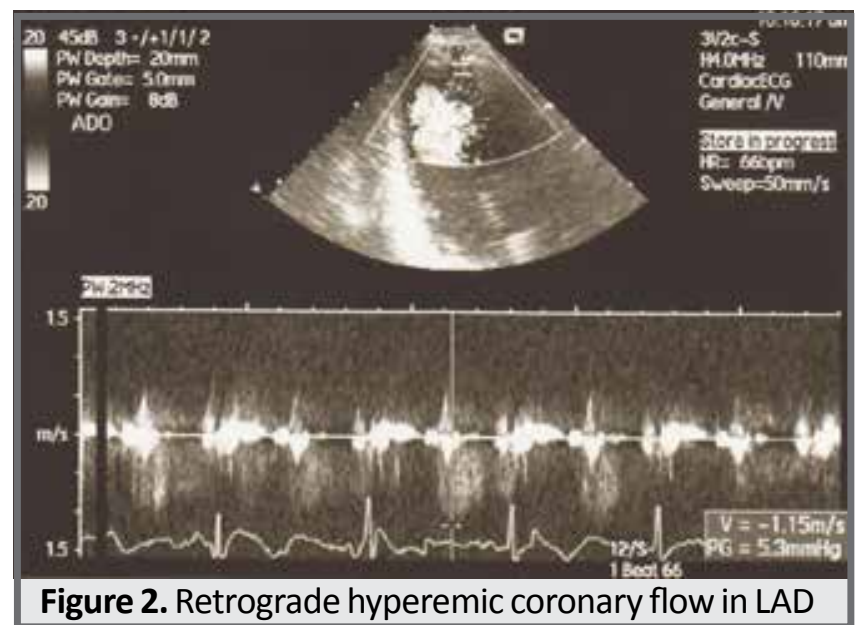

Address for correspondence: Ivana Rakočević, Cardiology clinic, Clinical center of Serbia, Mail: ivanarakocevic@hotmail.com 


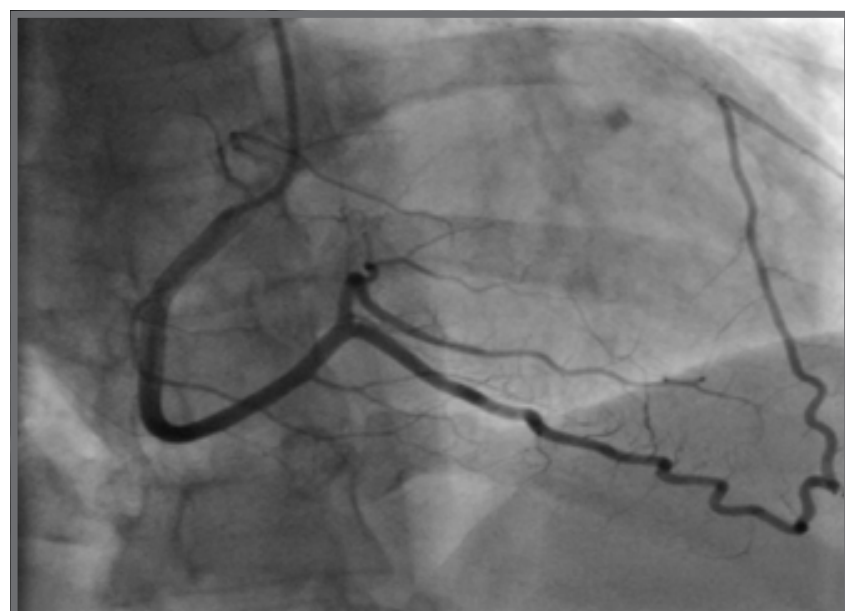

Figure 3. RCA with colleratels to LAD (Rentrop 3)

mild, nonsignificant ST and T changes in precordial leads and stress echo was suggestive of wall motion abnormality only in the anterior septal region.

In order to resolve this borderline finding of stress echo, patient was referred for transthoracic 2D echo assessment of CFR in the distal LAD. We performed the transthoracic Doppler echocardiography (TTD) with adenosine. The retrograde coronary flow was detected and this rise a suspicion of LAD proximal occlusion. Retrograde flow could be find distal to the site of a total occlusion in native artery in the presence of the patent graft or in this case in functional collateral artery at rest. The flow in this conduit behave in the same manner if the microcirculation is preserved ie. increase with hyperaemia (Figure 1 and 2) and allow assessment of coronary flow reserve. In our case CFR was 1.95 , considered as functionally sufficient for grafts and collateral circulation.

To further assess this unusual CFR and stress echo findings, the patient underwent repeated coronary angiography which showed complete in-stent occlusion of the proximal to middle LAD with well-developed collaterals from RCA (Rentrop 3) up to the LAD-diagonal bifurcation (Figure 3).

\section{Discussion}

It is known that collaterals will regress once the native artery that was replaced by the collaterals is revas- cularized. This process starts immediately after the reestablished antegrade flow with immediate loss of collateral conductance, and extends further many months after the angioplasty or revascularization procedure ${ }^{3}$. The incidence of $\mathrm{Ml}$ in case of reocclusion after a successful recanalization in recent prospective studies is evidence for a collateral regression ${ }^{4,5}$.

As the patient had well developed collaterals; symptom free during exertion, with maximal exercise showing only limited induced myocardial ischemia on up to two segments, and the value of CFR correspondent to excellent collaterals, the patient was left on medical therapy.

\section{Conclusion}

Collateral circulation is important in preserving ventricular function in coronary artery disease with total occlusion $^{6}$.Stil, during exercise these collaterals are limited in their functional reserve ${ }^{3,7}$. The symptomsand prognosis among these patients depend on the quality of the collateral circulation. CFR carries excellent longterm prognosis, and this case demonstrates excellent functional capacity of the collaterals as detected by „retrograde" CFR.

\section{References}

1.Berry C, Balachandran KP, L'Allier PL, et al. Importance of collateral circulation in coronary heart disease. Eur Heart J 2007; 28: 278-91.

2. Pizzuto F, Voci P, Puddu PE, et al. Functional assessment of the collateral-dependent circulation in chronic total coronary occlusion using transthoracic Doppler ultrasound and venous adenosine infusion. Am J Cardiol 2006;98:197-203.

3. Werner GS. The role of coronary collaterals in chronic total occlusions. Current Cardiology Reviews 2014 ;10: 57-64.

4. Sirnes PA, Golf S, Myreng Y, et al. Stenting in chronic coronary occlusion (sicco): A randomized, controlled trial of adding stent implantation after successful angioplasty. J Am Coll Cardiol 1996; 28: 1444-51.

5. Buller CE, Dzavik V, Carere RG, et al. Primary stenting versus balloon angioplasty in occluded coronary arteries: The total occlusion study of canada (TOSCA). Circulation 1999; 100: 236-42.

6. de Agustín JA, Marcos-Alberca P, Hernández-Antolín R, et al. Collateral circulation from the conus coronary artery to the anterior descending coronary artery: assessment using multislice coronary computed tomography. Rev Esp Cardiol 2010; 63: 347-51.

7. Werner GS, Figulla HR. Direct assessment of coronary steal and associated changes of collateral hemodynamics in chronic total coronary occlusions. Circulation 2002; 106: 435-40.

\section{Sažetak \\ Značaj retrogradnog koronarnog protoka nakon primarne $\mathrm{PCI}$}

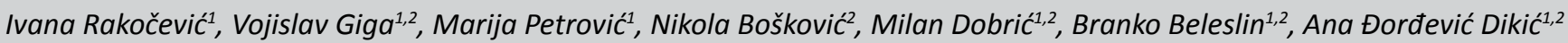
${ }^{1}$ Klinika za kardiologiju, Klinički centar Srbije, ${ }^{2}$ Medicinski fakultet, Univerzitet u Beogradu, Srbija

Koronarne kolateralne arterije predstavljaju alternativni put krvi kod koronarne obstruktivne bolesti srca. Kolateralna cirkulacija je značajna u očuvanju funkcije leve komore u slučaju totalne okluzije koronarne arterije. Ipak, tokom fizičkog opterećenja kolateralni krvni sudovi imaju ograničen funkcionalnu rezervu. Ovim prikazom slučaja smo pokazali neuobičajen nalaz stresne ehokardiografije I koronarne rezerve protoka kod pacijenta nakon primarne perkutane koronarne intervencije ( $p P C I)$. S obzirom na ograničenu zonu opterećenjem izazvane miokardne ishemije, i na nalaz retrogradnog koronarnog protoka sa vrednošću CFR koji ukazuje na odlično razvijene kolaterale kod bolesnice je indikovan nastavak optimalne medikamentne terapije, iako je ponovna koronarografija pokazala komplentnu in-stent okluziju LAD sa dobro razvijenim kolateralama.

Ključne reči: koronarne kolaterale, koronarna rezerva protoka 